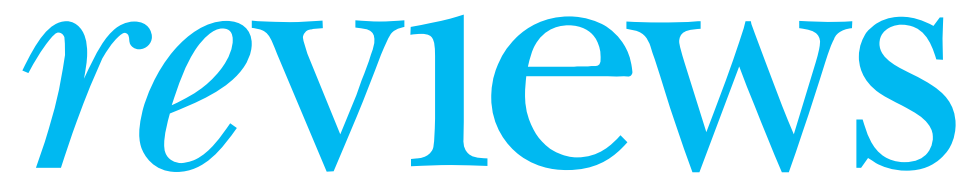

BOOKS • CD ROMS • ART •WEBSITES $\bullet$ MEDIA $\bullet$ PERSONAL VIEWS $\bullet$ SOUNDINGS

\section{The Great Betrayal: Fraud in Science}

Horace Freeland Judson

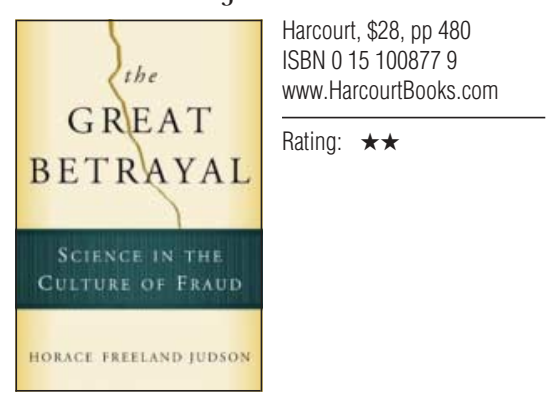

$\mathrm{T}$ he Great Betrayal describes many cases of research fraud. Why is the academic establishment reluctant to admit that fraud is a major problem? Possibly because the most influential academics obtained their seniority from research publications rather than by their teaching or practical skills. To suggest that their positions were attained in a corrupt system reduces their status.

As with other forms of clandestine dishonesty we can be certain that for every case of research fraud that is exposed others go undetected. In the cleverest financial or art frauds the victims do not even know they were duped. Ultimately it is the taxpayers who pick up the bill for research fraud and are its victims, but patients suffer directly when medical research is falsified.

Most cases of research fraud collated by Judson have been described before, but in many cases he has new information from interviews with the people involved. Therein lies a problem. Have people told him the truth-or what they want history to record?

In the cases where I have direct knowledge there are some inaccuracies. Judson states: "The case of Robert Slutsky, in itself, was comparatively uncomplicated and was handled expeditiously and effectively." Slutsky was not exposed until 1985, when he resigned as a cardiological radiologist at the University of California at San Diego Medical School, although many people knew much earlier that he falsified his research. I have described how, in 1982 when I visited friends in San Diego and gave a talk to cardiologists, medical staff working in many departments knew of Slutsky's frauds. The wife of a doctor who worked with him told me that she was concerned that her husband's reputation would suffer when Slutsky was exposed (Slutsky often persuaded scientific colleagues to add their names to his articles). Slutsky did not attempt to hide his dishonesty. He told me that he had always known that the work of John Darsee, a former researcher at the department of cardiology, Harvard, was suspect, because Darsee was the only person who had published more than him. Judson also describes Darsee's fraudulent publications, which were eventually exposed by the US Institutes of Health. Darsee's dishonesty was also known to colleagues and the departmental head long before he was exposed.

We cannot be complacent, because some cases of research fraud in Britain have been dealt with only a decade after they became common knowledge.

\section{I am afraid that research fraud often flourishes where there is already a climate of dishonesty}

Judson cites the case of Malcolm Pearce at St George's Hospital, London, as an example of an institution handling allegations speedily and well. Pearce, a gynaecologist, was found to have fabricated scientific data in the British Journal of Obstetrics and Gynaecology, and was struck off the medical register. In fact the hospital authorities took action only after a reporter from the Daily Mail and investigative journalists from the BBC television programme Horizon began to interview staff and indicated their intention to make the allegations public.

If, in the cases that I know about, things are different from the way Judson reports them, can I rely on his other sources?

Judson says, "Fabricators and falsifiers in the sciences originate their frauds alone. One rarely finds conspiracies to commit them." I know of cases where frauds were instigated by the department head, and junior researchers were pressed into cooperation. Judson also believes that junior researchers slip by default into research fraud because of inadequate supervision or mentoring. A doctor that I reported to the General Medical Council was advised by a senior colleague of tricks to get away with dishonesty. A junior doctor who received the same advice from the consultant told me. I am afraid that research fraud often flourishes where there is already a climate of dishonesty.

Judson only briefly describes what may be the most common form of research misconduct: failure to publish results. Many cases have been documented in which drug companies suppressed research findings for the sake of company profits. Journal editors distort the scientific record because they are reluctant to publish studies that failed to replicate research, and they are unwilling to retract flawed and dishonest reports.

Judson paints a rosier picture of the mechanisms for dealing with research fraud than I recognise. In the main he describes ways of dealing with allegations of misconduct in the United States. However, in the case of David Baltimore and ImanishiKari, to which Judson devotes a chapter of over 60 pages, one is left uncertain about who was guilty of what. Though ahead of the rest of the world it is clear that US mechanisms for dealing with research fraud are inadequate. British authorities lag far behind, and some countries have no mechanisms. Certainly the legal systems in some countries present obstacles to investigations. The British libel laws are major hurdles.

Judson believes that the era of internet publication will do much to prevent research fraud. It will allow open or public peer review; but will that ensure that the original data were genuine? How do we work out what is the definitive paper, when data interpretation has been amended by anyone who cares to get involved, whether or not they have expertise in that subject? Internet and electronic banking have increased the risk of major financial fraud, assisted laundering of money from drug dealing, and increased credit card fraud. The internet facilitates child pornography. The lack of regulation on the internet allows people to get medical advice and prescription drugs from quacks. The internet has increased plagiarism by students. I fear that publication of research on the internet will not safeguard the integrity of scientific research.

Peter Wilmshurst consultant cardiologist, Royal Shrewsbury Hospital, Shrewsbury peter.wilmshurst@rsh.nhs.uk

Competing interests: I have written and lectured on the subject of research misconduct, and I have reported doctors to the General Medical Council and other authorities for research misconduct. 


\section{Philosophy for Medicine: Applications in a Clinical Context}

Eds Martyn Evans, Pekka Louhiala, Raimo Puustinen

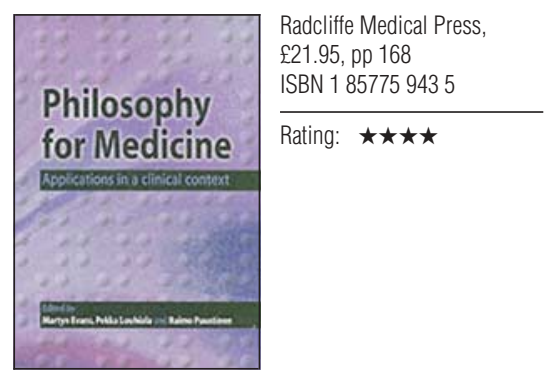

$\mathrm{A}$ lthough clinical medicine bristles with philosophical questions, in the moral decisions of everyday medical practice we do not always contemplate them very deeply, but rather make our judgments fairly intuitively. However, as Philosophy for Medicine emphasises, our intuitive moral thinking is by no means disconnected from philosophical theory.

The book is very easy to understand. It starts with an introductory section that frees

$F M$

\section{The Other Medicine}

BBC Radio 4, 21 September to 2 November at $9 \mathrm{pm}$

www.bbc.co.uk/radio4/science/

other_medicine.shtml

Rating: $\star \star \star$

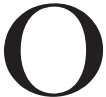

ne in four UK residents regularly uses complementary and alternative therapies, spending a total of more than £1bn (\$1.8bn; €1.4bn) a year. This six part series aims to explore this "other medicine"-why so many people are attracted to it, what is the evidence, if any, that it works, how it can affect our health and wellbeing, and whether it will ever become fully integrated with NHS care.

Presenter Anna Ford speaks to patients and practitioners, researchers and scientists, sceptics and believers, and we even witness her own sessions with alternative therapists (she is, her therapist tells her, apparently suffering from post-menopausal yin deficiency). But Ford restricts herself to only a few personal comments, mostly letting us hear from her guests. And there are almost as many different messages as there are interviewees.

For those of us who believe in the principles of evidence based medicine, there is little choice but to apply the same criteria to other healing methods. Many epidemiological studies of alternative treatments come the reader from any fear that "philosophical things" are difficult to grasp. It defines "philosophy" in this context by asking us not to take for granted the things we normally take for granted. Doctors are encouraged to recognise and reflect on the philosophical questions arising during clinical practice.

The authors emphasise the clinical encounter as the core of medicine: "The medical consultation establishes the conditions and framework within which scientific work with patients proceeds." During a medical consultation doctors are repeatedly confronted with a variety of human phenomena that cannot be approached or solved by the methods of biological sciences alone.

However, without ignoring the efficacy and strength of biomedicine the authors question the relation between the concept of evidence and the concept of truth. From a philosophical point of view, "There is fairly widespread agreement that no satisfactory theory of truth exists at present." The authors conclude that the discussion about evidence based medicine is superficial. The book does, however, discuss the most common theories of truth in the context of medicine.

Regarding aesthetics of clinical practice, the book reminds us that the separation of science from art has been a relatively recent phenomenon in Western medicine. In addition to biomedical scientific facts, doctors are called on to take into account their patients' emotions and cultural backgrounds; clinicians have a responsibility to be sensitive to the quality of service they deliver.

Doubt and uncertainty are acknowledged as being daily elements of a doctor's work. The authors discuss different types of uncertainty in the context of clinical work. Even if "the power of the randomized controlled trial is considerable," we cannot always be absolutely sure whether conclusions can be extrapolated to the individual patient we are treating.

"We can never be absolutely sure of what we do, but we have to accept our personal responsibility to do our best in the absence of final truths." This simple but profound message-together with the reminder that the primary aim of medical endeavour is to take care of sick patients-is what makes Philosophy for Medicine valuable reading for all clinicians.

Markku Timonen acting professor of public health science, University of Oulu, Finland

markku.timonen@oulu.fi from teams lead by Edzard Ernst, who in 1993 came from Vienna to London to become Britain's first professor of complementary medicine (at Peninsula Medical School). Professor Ernst tells us: "A lot of people 10 years ago and some people even today would say that science shouldn't touch complementary medicine because it will destroy it, complementary medicine cannot be squeezed into the straitjacket of a clinical trial and so forth. I think that's just a cliché-a tired cliché on top of it."

However, the alternative camp repeatedly claims that diagnosis and treatment are an individual thing in complementary medicine, and that a randomised controlled trial "simply isn't the appropriate tool for finding out if therapy works or not." The episodes that had been broadcast so far as the BMJ went to press (which can all be heard again on the website and downloaded as tran-

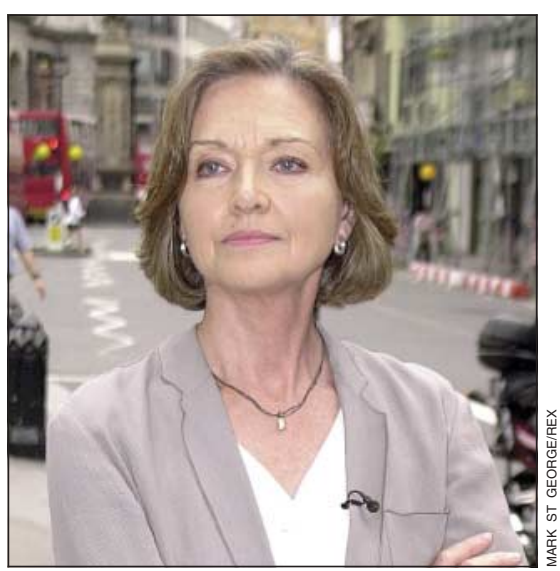

Yin up: presenter Anna Ford scripts) have almost equated scientific methodology with randomised controlled trials. However, quality observational studies can provide evidence too, and are probably more appropriate study designs for research in complementary medicine.

Former BMJ editor Richard Smith tells Ford, "You can get any rubbish published, just go down and down and down and down the food chain [of medical journals]," reminding us again of the great need for critical appraisal skills among doctors. Dr Smith also says that researchers in complementary medicine are in "a bit of a catch 22" position because they have difficulties getting the funds to do research.

George Lewith, a researcher in complementary and alternative medicine at the University of Southampton, believes that "it's all about this battle, this process of who owns health." Political economics, the cost of medicine, and the power of monopolies, all addressed in this series, certainly play a role in untangling the Gordian knot of traditions of healing.

I have had various personal and professional experiences of both traditional and complementary medicine. In general it seems to me that complementary therapists are better at reaching out to patients' souls than conventional doctors, and this may be where their success lies. One reason for this might be that complementary therapists are able to dedicate more time to a particular patient, but I fear that that is not the only reason.

Kristina Fišter editorial registrar, BMJ kfister@bmj.com 


\section{Palestine: the assault on health and other war crimes}

$\mathrm{D}$ oes the death of an Arab weigh the same as that of a US or Israeli citizen? The Israeli army, with utter impunity, has killed more unarmed Palestinian civilians since September 2000 than the number of people who died on September 11, 2001. In conducting 238 extrajudicial executions the army has also killed 186 bystanders (including 26 women and 39 children). Two thirds of the 621 children (two thirds under 15 years) killed at checkpoints, in the street, on the way to school, in their homes, died from small arms fire, directed in over half of cases to the head, neck and chest-the sniper's wound. Clearly, soldiers are routinely authorised to shoot to kill children in situations of minimal or no threat. These statistics attract far less publicity than suicide bombings, atrocious though these are too.

Amnesty International has called for an investigation into the killing of Asma al-Mughayr (16 years) and her brother Ahmad (13 years) on the roof terrace of their home in Rafah on 18 May, each with a single bullet to the head. Asma had been taking clothes off the drying line and Ahmad feeding pigeons. Amnesty noted that the firing appeared to have come from the top floor of a nearby house, which had been taken over by Israeli soldiers shortly before. Amnesty suspects that this is not "caught in crossfire," this is murder.

Israeli military reoccupation of the West Bank and Gaza-a system of military checkpoints splitting towns and villages into ghettos, curfews, closures, raids, mass demolition and destruction of houses (more than $60000)$, and land expropriations-has made ordinary life impossible for everyone, and is driving Palestinian society and its institutions towards destitution. Moreover, Israel has been constructing a grotesque barrier that, when completed, will total over 400 miles-four times longer than the Berlin
Wall. Extending up to 15 miles into Palestinian territory, the real purpose of the wall is permanently to lock more than 50 illegal Israeli settlements into Israel proper. This is expansive, aggressive colonisation, in defiance of the International Court of Justice in The Hague and the United Nations General Assembly resolution of last July.

Last year a UN rapporteur concluded that Gaza and the West Bank were "on the brink of a humanitarian catastrophe." The World Bank estimates that $60 \%$ of the population are subsisting at poverty level (£1.12; \$2; €1.6 per day), a tripling in only three years. Half a million people are now completely dependent upon food aid, and Amnesty International has expressed concern that the Israeli army has been hampering distribution in Gaza. Over half of all households are eating only one meal per day. A study by Johns Hopkins and Al Quds universities found that $20 \%$ of children under 5 years old were anaemic, $9.3 \%$ were acutely malnourished, and a further 13.2\% chronically malnourished. The doctors I met on a professional visit in March pointed to a rising prevalence of anaemia in pregnant women and low birthweight babies.

The coherence of the Palestinian health system is being destroyed. The wall will isolate 97 primary health clinics and 11 hospitals from the populations they serve. Qalqilya hospital, which primarily serves refugees, has seen a $40 \%$ fall in follow up appointments because patients cannot enter the city. There have been at least 87 documented cases (including 30 children) in which denial of access to medical treatment has led directly to deaths, including those of babies born while women were held up at checkpoints. The checkpoint at the entrance to some villages closes at $7 \mathrm{pm}$ and not even ambulances can pass after this time. As a recent example, a man in a now fenced in village near Qalqilya approached the gate with his seriously ill daughter in his arms, and begged the soldiers on duty to let him pass so that he could take her to hospital. The soldiers refused, and a Palestinian doctor summoned from the other side was also refused access to the child. The doctor was obliged to attempt a physical examination, and to give the girl an injection, through the wire.

There are consistent reports of ambulances containing gravely ill people being hit by gunfire, or detained at checkpoints while drivers and paramedics are interrogated, searched, threatened, humiliated, and assaulted. Wounded men are abducted from ambulances at checkpoints and sent directly to prison. Clearly marked clinics are fired on, and doctors and other health workers shot dead on duty.

Physicians for Human Rights (Israel) have lambasted the Israeli Medical Association (IMA) for its silence in the face of these systematic violations of the Fourth Geneva Convention, which guarantees the right to health care and the protection of health professionals as they do their duty. Remarkably, IMA president Dr Y Blachar is currently chairperson of the council of the World Medical Association (WMA), the official international watchdog on medical ethics. A supine BMA appears in collusion with this farce at the WMA. Others are silenced by a fear of being labelled "anti-semitic," a term used in a morally corrupt way by the pro-Israel lobby in order to silence. How are we to affect this shocking situation, one which to this South Africanborn doctor has gone further than the excesses of the apartheid era.

Derek Summerfield honorary senior lecturer, Institute of Psychiatry, London derek.summerfield@slam.nhs.uk

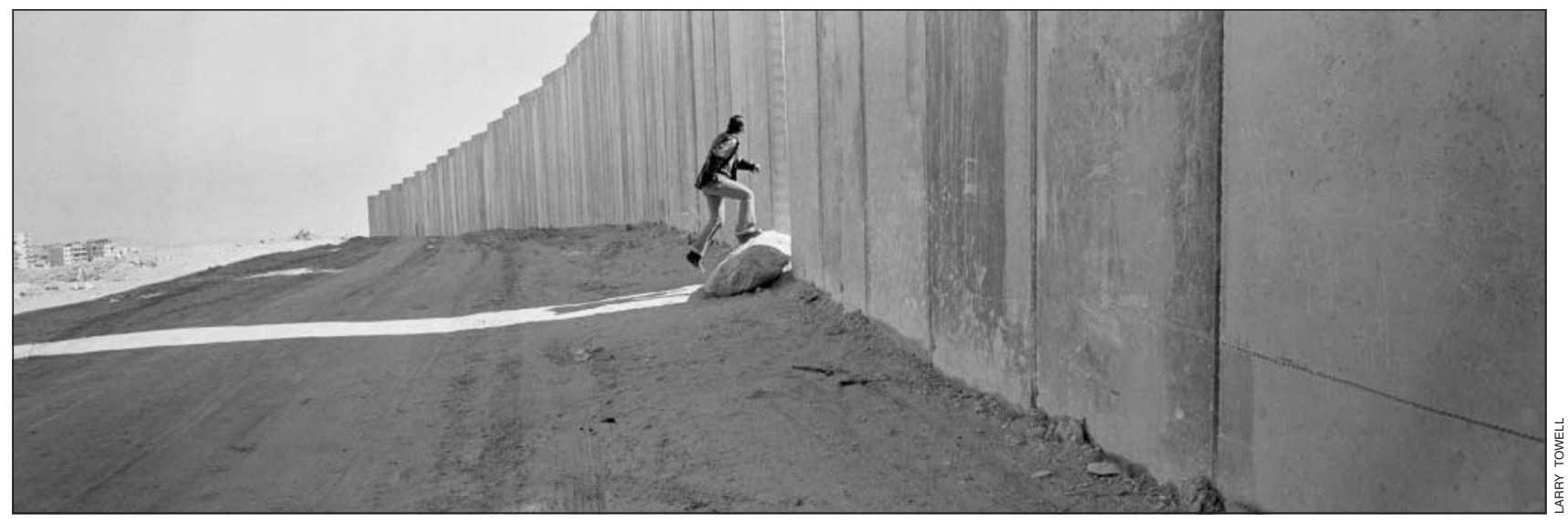

The wall will isolate 97 primary health clinics and 11 hospitals from the population they serve 
SOUNDINGS

\section{Doctors playing at politics}

I

n 2003 the New Zealand Ministry of Health funded an update of the New

Zealand stroke guideline (available at www.stroke.org.nz). As part of the launch of the guideline the minister of health hosted a parliamentary function. As a co-editor of the guideline I was invited to speak for five minutes on its main points. What follows is my description of the experience of trying to get an important message across to a political audience in a short space of time.

The minister of health is in the front row. Maori greetings, responses, and waiata (songs) are completed. Caterers' trays jingle in the background. How do you say, in five minutes, something that will make a minister sit up and act? Did I miss this bit of the medical curriculum? "Ten easy ways to convince politicians and civil servants"? Perhaps not.

This launch represents the work of dozens of clinicians, consumers, and voluntary organisations putting the case for better service delivery for people at risk of stroke and better management of stroke patients. We all know how relatively easy it is to write the guideline, but how difficult it is to get it implemented. Getting on to the minister's radar screen would be a good start.

So, a big breath, and: "Ladies and gentlemen."

I miss out the greeting in Maori after advice from a Maori colleague: "Unless you feel totally confident you'll sound a complete prat."

"In the next five days 100 New Zealanders will have a stroke." I run through the grim outcome statistics. Is the audience looking a shade uneasy now?

"But, yes, there is a treatment that can make a substantial difference to these outcomes-not a drug but an organisational change to services. Organised stroke services, including stroke unit care for all people with stroke ... . fantastic evidence . . . will reduce costs in the long run."

The unease has turned back to comfort. They've heard this before-in a briefing 30 minutes ago. I look the minister in the eyes and launch phase two.

"The only problem is that 'organised stroke services' were recommended in the 1996 stroke guideline. Successive ministries of health have let down the people of New Zealand by failing to implement those recommendations. In that time 1500 preventable deaths from stroke have occurred, and potential savings of tens of millions of dollars have been missed."

The minister momentarily goes slackjawed but rapidly readjusts the fixed smile and stares back. The other ministry people start fidgeting and tap meaningfully at their palmtops.

Minutes tick by. Get to the bottom line: money for implementation. A one-off payment by the health ministry of $\$$ NZ1000 (£370; \$670; €540) for each new stroke patient this year-the cost of a magnetic resonance image or a couple of days in hospital.

And then it is over. Friends in the audience give a thumbs up and there is scattered applause. The minister is impassive.

Suddenly, without realising it at first, I am hit by a blanket defensive pattern. The minister and sidekick, smiling, ask 10 surefooted questions then intercept the hovering media people and smother them with the party line: "Yes, better stroke services are what we want. Yes, the ministry is working with 'the sector' to deliver best outcomes for stroke patients. But, no, the ministry doesn't have a big pot of money. The district health boards are now the funders of health services, so you will have to ask [all 22 of] them how they are going to deliver better stroke services."

I have visions of Lawrence Dallaglio, superbly skilled at slowing down play, killing the ball, and kicking the goals that count. I check my face for sprig marks: no worse than usual.

The ministerial party disappears for another function. The media people start asking questions. I babble, knowing the game is lost. The reporter seems to have got the wrong end of the stick and repeats a few things the minister has said. "But, but ..." I stammer, and they are gone. It will sound even worse on the radio the next day. I grab a glass of red wine, accept some well meant congratulations, then wander outside to catch my train home.

Can any lessons be learnt from this? Possibly. Firstly, these people are professionals, well coached and with a clear game plan. A nice turn of phrase and a bunch of randomised controlled trials won't usually be enough. Pushing funding and responsibility out to the district health boards is an effective defence against calls for national action. Secondly, we're amateurs. We are not trained in the dark arts of politics and media relations, and apart from some gifted individuals we get taken to the cleaners every time. But you have to play this game. Luck plays some part, and maybe in the end you do score some points in the war, even if you lose many of the battles. You have to be seen to mean it and be prepared to take the public hits to make progress in the back rooms where, eventually, the deals get done.

And yes, even rugby world champions lose sometimes.

Harry McNaughton rehabilitation physician, Medical Research Institute, Wellington, New Zealand harry.mcnaughton@mrinz.ac.nz

\section{The gas we pass}

Benjamin Franklin once wrote that "it is universally known that in digesting our common food there is produced in the bowels of human creatures a great quantity of wind." As escaping gas is offensive because of its smell, and retained gas causes pain and disease, he wished one would discover a drug that "shall render the natural discharges of wind from our bodies, not only inoffensive, but agreeable as perfumes."

Alas, no such agent has ever been discovered. Coming closest, as we learn from Jim Dawson's 1999 book Who Cut the Cheese: A Cultural History of the Fart (Ten Speed Press), was the Italian courtesan who in the company of her paramours would surreptitiously crush a vial of perfume while simultaneously making an audible sound.

Mr Dawson informs us that less than $1 \%$ of the intestinal gas (ammonia, skatole, hydrogen sulfide) is malodorous. The other gases (nitrogen, hydrogen, carbon dioxide, methane, oxygen) are odourless. The gases are produced by E coli and other bacteria fermenting oligosaccharides that originate from milk products, bread, fruits, and vegetables, especially beans. Each day a human generates a litre of gas; an elephant, a thousand litres of methane. Climatic changes have been attributed to emissions from dinosaurs; the greenhouse effect to methane from cows.

Hippocrates, Petronius, Montaigne, and Sir Thomas Moore believed that holding back gas was harmful. In $\mathrm{AD} 41$ the emperor Claudius planned to legitimise passing wind at banquets. In 1975 Dr Wynne Jones proposed that retention of flatus caused diverticular disease and recommended passing flatus at every act of micturition (Lancet 1975;2:211). He also advised exercise, as did the researchers who pumped air into volunteers and found that pedalling on a bike facilitated gas evacuation and relieved bloating (American Journal of Medicine 2004;116:536-9).

In his book Mr Dawson classifies emissions into explosive, thunderous, repetitive, and musical. The word itself comes from the Indo-European root "pert." Said to be more offensive to Protestant than to Catholic ears, it was labelled "not in decent use" in the early Oxford English Dictionary, omitted by Webster's in 1909, but reinstated in 1961. For many it remains what Edward Gibbon would have called "an indelicate subject of conversation.”

George Dunea attending physician, Cook County Hospital, Chicago, USA 